\title{
Acaricidal properties of ylang-ylang oil and star anise oil against nymphs of Ixodes ricinus (Acari: Ixodidae)
}

\author{
Fawzeia Elmhalli ${ }^{1}$ (D) $\cdot$ Katinka Pålsson ${ }^{2} \cdot$ Jan Örberg $^{3} \cdot$ Giulio Grandi $^{4}$
}

Received: 18 April 2018 / Accepted: 27 September 2018 / Published online: 9 October 2018 (C) The Author(s) 2018

\begin{abstract}
Ylang-ylang oil (YYO) from Cananga odorata (Lam.) Hook.f. \& Thomson and star anise oil (SAO) from Illicium verum Hook.f. were tested at four concentrations 0.05, 0.1, 0.2, $0.4 \mu \mathrm{l} / \mathrm{cm}^{2}$. Mortality rates were obtained by counting dead nymphs at 30 -min intervals during the first $5 \mathrm{~h}$ after the start of exposure and then at 24, 48 and $72 \mathrm{~h}$. Mortality increased with increasing oil concentration and time of exposure. The two highest concentrations of YYO $\left(0.2,0.4 \mu \mathrm{l} / \mathrm{cm}^{2}\right)$ gave maximum lethal concentrations (LC) of 50 and $95 \%$ mortality after $4.5 \mathrm{~h}$ exposure. Mortality of $95 \%$ was obtained after $24 \mathrm{~h}$ with the next highest dose $\left(0.1 \mu \mathrm{l} / \mathrm{cm}^{2}\right)$, whereas $\mathrm{LC}_{95}$ required 3 days with the lowest YYO $\left(0.05 \mu \mathrm{l} / \mathrm{cm}^{2}\right)$. The lethal effect time (LT) was correlated with the duration of exposure, with a significant effect at $0.4 \mu \mathrm{YYYO} / \mathrm{cm}^{2}$ after $3 \mathrm{~h}$ ' $\left(\mathrm{LT}_{50}=3.2 \mathrm{~h}, \mathrm{LT}_{95}=4.3 \mathrm{~h}\right)$. In contrast, only the highest concentration of SAO, $0.4 \mu \mathrm{SAO} / \mathrm{cm}^{2}$, showed increasing mortality with time of exposure. This reached $\mathrm{LT}_{50}$ after $10 \mathrm{~h}$ and $\mathrm{LT}_{95}$ after $24 \mathrm{~h}$. However, with the lower concentration $(0.2 \mu \mathrm{l} /$ $\left.\mathrm{cm}^{2}\right) 50 \%$ mortality was reached after $24 \mathrm{~h}$ and $100 \%$ at $72 \mathrm{~h}$. At to the lowest concentration of SAO $\left(0.1 \mu \mathrm{l} / \mathrm{cm}^{2}\right), 67 \%$ mortality after $48 \mathrm{~h}$. The study indicates that YYO and SAO exhibit strong acaricidal properties against nymphs of I. ricinus and suggest that both YYO and SAO should be evaluated as potentially useful in the control of ticks.
\end{abstract}

Keywords Acaricide $\cdot$ Cananga odorata $\cdot$ Illicium verum $\cdot$ Ixodes ricinus

Fawzeia Elmhalli

fawzeia.elmhalli@ebc.uu.se

1 Department of Systematic Biology, Evolutionary Biology Centre, Uppsala University, Norbyvägen 18d, SE-752 36 Uppsala, Sweden

2 Ecological Chemistry Group, Department of Chemistry, School of Chemical Sciences and Engineering, Royal Institute of Technology, Stockholm, Sweden

3 Department of Environmental Toxicology, Evolutionary Biology Centre, Uppsala University, Uppsala, Sweden

4 Department of Biomedical Sciences and Veterinary Public Health, Swedish University of Agricultural Sciences (SLU), Uppsala, Sweden 


\section{Introduction}

Ticks (Acari: Ixodoidea) are obligatory blood-sucking arthropods and are among the most harmful ectoparasites and most important disease vectors of domestic and wild animals (Randolph 1998). These arachnids can directly cause tick paralysis, physical irritation and allergic reactions. Most importantly, ticks are major vectors of human pathogens (Estrada-Peňa and Jongejan 1999; Sonenshine 2003).

One of the medically most important tick species is Ixodes ricinus L., which is common throughout most of Europe and maybe established locally in parts of North Africa (Zhioua et al. 1999; Sarih et al. 2003). Due to its widespread distribution, catholic feeding habits and because of its willingness to bite humans, I. ricinus is the most important European vector of many pathogens, such as tick-borne encephalitis virus (TBEV), the protozoan parasite Babesia divergens (M'Fadyean and Stockman 1911) and several bacteria, e.g. Anaplasma phagocytophilum, several rickettsiae and the Lyme borreliosis spirochetes.

These and other tick-transmitted infections might be controlled and/or reduced by minimizing human contact with high-risk tick-infested habitats. However, this is often not practical. One widely used method for controlling tick populations affecting domesticated animals is based on the limited application of synthetic acaricides, such as pyrethroids, onto the animals or in their habitat. However, these substances often cause toxic reactions when applied on domestic animals and can potentially harm the environment. Consequently, a simple and cheap method of protecting humans and domestic animals against ticks is needed.

Plant extracts have been used for millennia to attempt to control arthropod pests, so there is a potential for discovery of effective plant products for tick control (SilvaAguayo 2004; Katinka et al. 2008). Many natural substances have a relatively low mammalian toxicity and degrade rapidly in the environment, properties that make them attractive alternatives to many synthetic acaricides currently in use (Papachristos et al. 2004; Kim et al. 2007; De Souza Chagas et al 2012). This study investigates the potential utility for control of ticks of two naturally occurring essential oils, ylang-ylang oil (YYO) from Cananga odorata (Lam.) Hook.f. \& Thomson (Annonaceae) and of star anise oil (SAO) obtained from Illicium verum Hook.f. (Illiciaceae). The toxic properties of these essential oils have, to our knowledge, not previously been investigated as acaricides against $I$. ricinus. We evaluate the toxicity of these oils against nymphs of $I$. ricinus, including their maximal lethal concentrations.

\section{Materials and methods}

Unfed nymphs of $I$. ricinus were collected in a woodland area 6-8 $\mathrm{km}$ south of Uppsala city, east-central Sweden, during April-September 2006. Ticks were collected by dragging a $1-\mathrm{m}^{2}$ light-coloured flannel cloth over the ground vegetation (Mejlon and Jaenson 1993). The cloth was inspected at every $10 \mathrm{~m}$ step when all nymphs adhering to the cloth were collected. Nymphs were maintained at $85-95 \%$ relative humidity (RH) and $\approx 4{ }^{\circ} \mathrm{C}$ in complete darkness for 2 months. Before testing, the nymphs were allowed to adapt to the test environment $\left(21-23^{\circ}, 85-95 \% \mathrm{RH}\right)$ for $4 \mathrm{~h}$. 


\section{Substances tested}

Star anise oil and ylang-ylang oil were bought from www.crearome.se. Star anise oil was obtained by stem distillation from the fruits and seeds of the Chinese star anise $I$. verum, which is grown almost exclusively in southern China and Japan. The dried fruits may contain 5-8\% of essential oil, consisting predominately (85-90\%) of anethole, i.e., trans-1-methoxy-4-(prop-1-enyl) benzene. Phellandrene, safrole, 1,8-cineole, $\alpha$-terpineol, estragole, limonene, linalool, methyl-chavicol, para-anisaldehyde and trepinen-4-ol are known to be toxic to certain arthropods (Duke 2008).

Ylang-ylang oil is $100 \%$ oil from $C$. odorata cultivated on Madagascar, obtained by steam distillation of the flowers of $C$. odorata. The main constituents of the oil are linalool, $\beta$-caryophyllene, $\gamma$-muurolene and $\alpha$-trans, trans-farnesene (Baratta et al. 1998). Benzyl acetate, linalool, p-cresyl methyl ether and methyl benzoate give the oil its characteristic odor (Manner and Craig 2006).

\section{Assay 1: Open filter paper method (A)}

As shown in assay 1 the acaricidal effects of YYO and SAO against nymphs of $I$. ricinus were tested in a bioassay based on the "open filter paper method" as described in WHO (1996). Oils were tested in the laboratory at $21-23{ }^{\circ} \mathrm{C}$ and $85-95 \% \mathrm{RH}$. The number of dead ticks was counted using a dissection microscope at 25-50X magnification. Four concentrations of the two oils, YYO and SAO, were prepared by dissolving in $1 \mathrm{ml}$ of acetone. The resulting solutions were applied separately onto round Whatman filter paper no.1 to final concentrations of $0.05,0.1,0.2$ and $0.4 \mu \mathrm{loil} / \mathrm{cm}^{2}$. Filter papers impregnated with acetone were used as controls. The filter papers were placed at the bottom of plastic cups $\left(122 \mathrm{~cm}^{3}\right.$ volume), where the solvent evaporated completely within $20 \mathrm{~min}$. Ten randomlyselected tick nymphs were introduced into each plastic cup, which were then covered by fine-meshed cloth secured with rubber bands around the top to prevent the ticks' escape. Each cup was put separately into a closed plastic container with wet tissue paper at the bottom to maintain high humidity. Dead ticks were recorded every $30 \mathrm{~min}$ for the first $5 \mathrm{~h}$, and then at 24, 48 and $72 \mathrm{~h}$. The tests of each concentration were repeated five times.

Concentration-response curves were obtained by plotting the number of dead ticks, expressed as a percentage of the total number of individuals for each time of exposure versus the two oils' concentrations. $\mathrm{LC}_{50}$ and $\mathrm{LC}_{95}$ for the different exposure times were then determined from these concentration-response curves. Time-response curves were obtained by plotting the number of dead ticks, expressed as a percentage of the total number of individuals for each concentration, versus time of exposure. $\mathrm{LT}_{50}$ and $\mathrm{LT}_{95}$ were then determined from these time-response curves (Johnson et al. 1984).

\section{Assay 2: Limited exposure time method (B)}

Four concentrations of YYO and SAO corresponding to $0.05,0.1,0.2$ and $0.4 \mu \mathrm{l} / \mathrm{cm}^{2}$ in four replicates of each oil were prepared using the procedure described in method A. The effect on nymphal mortality of different exposure times was investigated as follows: six different batches of 10 nymphs each were placed in plastic cups with oil-impregnated filter paper and covered with fine-meshed cloth secured with rubber bands as in procedure A (above). Nymphs were kept on the oil-impregnated filter papers for 1.5, 2.0, 2.5, 3.0, 3.5 or $4.0 \mathrm{~h}$. After exposure, the nymphs were moved to un-impregnated filter paper, and 
mortality was checked by observing the ticks under a dissection microscope at 25-50X magnification every $30 \mathrm{~min}$ for $4.5 \mathrm{~h}$ and then at 24,48 and $72 \mathrm{~h}$. These tests were repeated three times. Time-response curves were obtained for each oil concentration by plotting the number of dead ticks, expressed as a percentage of the total number of individuals, versus time after the end of exposure. LT50 and LT95 were then determined from these timeresponse curves.

\section{Statistical analysis}

The data are expressed as the percentage mortality. Groups were compared using a twoway ANOVA for repeated measurements, and multiple regression test. Levene's test was used for equality of variances, and $t$-test for equality of means. The Multiple Range test (LDS) was used for post hoc analysis. A value of $p<0.05$ was considered significant.

\section{Results}

\section{Open filter paper method}

\section{Ylang-ylang oil}

For YYO, nymph mortality of nymphs increased with increasing oil concentration and time, reaching $100 \%$ mortality after $4.5 \mathrm{~h}$ for the group exposed to the highest YYO concentration $\left(0.4 \mu \mathrm{l} / \mathrm{cm}^{2}\right)$. With the lowest concentration $\left(0.05 \mu \mathrm{YYY} / \mathrm{cm}^{2}\right), 100 \%$ mortality was reached after $72 \mathrm{~h}$. The analysis of variance shows a highly significant difference in mortality rate among the controls and exposed nymphs $(\mathrm{F}=109.2, p<0.0001)$, and also among different exposure times (ET) for nymphs exposed to the same YYO concentration. After the nymphs were exposed to YYO for $2 \mathrm{~h}$ the p value was 0.005 which is considered significant, moreover with the longer ETs $(2.5-5 \mathrm{~h})$ it gave more significant toxicity results $(p<0.0001)$.

The lethal concentrations at different exposure times to YYO were calculated at $4.5 \mathrm{~h}$ $\mathrm{LC}_{95}=0.385-0.4 \mu \mathrm{l} / \mathrm{cm}^{2}$ of YYO (Table 1). Lethal times at different concentrations of YYO were calculated. The result was at $0.4 \mu \mathrm{l} / \mathrm{cm}^{2}$ of $\mathrm{YYO} \mathrm{LT}_{95}=4.4-4.5 \mathrm{~h}$ (Table 1). Moreover, it was observed that nymphs exposed to $0.2-0.4 \mu \mathrm{YYO} / \mathrm{cm}^{2}$ were not able to climb the wall of the cup, whereas nymphs exposed to $0.1 \mu \mathrm{YYO} / \mathrm{cm}^{2}$ started to climb as soon as they were placed in the cup. Then they stayed on the upper edge of the cup, as far away as possible from the impregnated filter papers, until they dropped down and became motionless.

\section{Star anise oil}

For SAO, only the ticks subjected to the highest concentration, $0.4 \mu \mathrm{SAO} / \mathrm{cm}^{2}$, showed increased mortality with increased time (Fig. 1c). This reached $50 \%$ mortality after $10 \mathrm{~h}$ and a maximum of $99 \%$ mortality after $24 \mathrm{~h}$. However, at the lower concentration $(0.2 \mu \mathrm{l}$ $\mathrm{SAO} / \mathrm{cm}^{2}$ ), $50 \%$ mortality was only reached after $24 \mathrm{~h}, 90 \%$ after $48 \mathrm{~h}$, and $100 \%$ at $72 \mathrm{~h}$. With the group exposed to the lowest concentration of SAO $\left(0.1 \mu \mathrm{l} / \mathrm{cm}^{2}\right), 67 \%$ mortality occurred after $48 \mathrm{~h}$, reaching $100 \%$ mortality by the third day (Table 2 ). The analysis of 
Table 1 The lethal concentrations at different exposure times to ylang-ylang oil (YYO), and lethal times at different concentrations of YYO, in method A

\begin{tabular}{lllllll}
\hline \multicolumn{2}{l}{ Lethal concentrations $(\mathrm{LC})$} & & \multicolumn{4}{l}{ Lethal time (LT) } \\
\cline { 1 - 1 } ET to YYO (h) & $\mathrm{LC}_{50}\left(\mu \mathrm{l} / \mathrm{cm}^{2}\right)$ & $\mathrm{LC}_{95}\left(\mu \mathrm{l} / \mathrm{cm}^{2}\right)$ & & $\begin{array}{l}\text { Conc. of } \mathrm{YYO} \\
\left(\mu \mathrm{l} / \mathrm{cm}^{2}\right)\end{array}$ & $\mathrm{LT}_{50}(\mathrm{~h})$ & $\mathrm{LT}_{95}(\mathrm{~h})$ \\
\hline 3 & 0.4 & - & 0.05 & 24 & 66 \\
3.5 & 0.31 & - & 0.1 & 22 & 47 \\
4 & 0.19 & - & 0.2 & 3.9 & 21 \\
$4.5^{*}$ & 0.185 & 0.385 & $0.4^{*}$ & 2.8 & 4.4 \\
5 & 0.16 & 0.36 & & & \\
24 & 0.049 & 0.29 & & & \\
48 & 0.03 & 0.09 & & & & \\
72 & 0.026 & 0.048 & & & & \\
\hline
\end{tabular}

*At $4.5 \mathrm{~h} \mathrm{LC}_{95}=0.385 \mu \mathrm{l} / \mathrm{cm}^{2}$ of $\mathrm{YYO} \approx 0.4 \mu \mathrm{l} / \mathrm{cm}^{2}$ of $\mathrm{YYO}$, and at $0.4 \mu \mathrm{l} / \mathrm{cm}^{2}$ of $\mathrm{YYO} \mathrm{LT}_{95}=4.4-4.5 \mathrm{~h}$. The data were calculated from the curves for different exposure times shown in Fig. 1b. and the curves of different concentrations shown in Fig. 1a

variance shows a significant difference between control and all substance concentrations $(\mathrm{F}=2.40, p<0.0001)$.

\section{Limited exposure time method}

\section{Ylang-ylang oil}

Nymph mortality was also measured by exposing them to $(0.1,0.2$ and 0.4$) \mu \mathrm{l} / \mathrm{cm}^{2} \mathrm{YYO}$ for varying lengths of time $(1.5,2.0,2.5,3.0,3.5$ or $4.0 \mathrm{~h})$. An analysis of variance of nymph death rate (\%) versus exposure time (ET) showed a highly significant difference in mortality rate between control versus exposed nymphs for different concentrations of YYO $(\mathrm{F}=24.9, p<0.0001)$. Figure $2 \mathrm{a}$ shows that at a concentration of $0.4 \mu \mathrm{l} / \mathrm{cm}^{2}$ there was a significant variation in mortality rate between nymphs for different ETs $(\mathrm{F}=30.48$, $p<0.0001$ ). After $1.5 \mathrm{~h}$ of exposure to $0.4 \mu \mathrm{l} / \mathrm{cm}^{2} \mathrm{YYO}$ the nymphs that had been moved away from the impregnated filter paper appeared weak and inactive. However, these nymphs recovered in fresh air and more than $75 \%$ were active and still alive even after $48 \mathrm{~h}$, and their mortality after $72 \mathrm{~h}$ in fresh air was less than $40 \%$. Even after 4 days, mortality among the exposed nymphs did not reach $50 \%$. On the other hand, $50 \%$ of nymphs which were exposed to $0.4 \mu \mathrm{l} / \mathrm{cm}^{2}$ YYO for $2 \mathrm{~h}$ were dead after $4 \mathrm{~h}$ in fresh air, and all were dead after $24 \mathrm{~h} .50 \%$ of the nymphs exposed to $0.4 \mu \mathrm{l} / \mathrm{cm}^{2}$ YYO for $2.5 \mathrm{~h}$ were dead after $2.5 \mathrm{~h}$ in fresh air, and all were dead after $3.9 \mathrm{~h}$. After $3.0 \mathrm{~h}$ ' exposure, $100 \%$ mortality occurred after $1.5 \mathrm{~h}$ in fresh air, which means that the total time after the nymphs were exposed and moved out was $4.5 \mathrm{~h}$, whether they had been moved to fresh air or not. In contrast, Fig. 2b. shows that at $0.2 \mu \mathrm{l} / \mathrm{cm}^{2}$ of YYO there was no significant difference in mortality rate between different ETs. Only nymphs exposed to YYO for $3.0 \mathrm{~h}$ or longer reached $50 \%$ mortality after 2.5 and $2 \mathrm{~h}$ in fresh air, and $100 \%$ mortality between 4.5 and $24 \mathrm{~h}$. With $0.1 \mu \mathrm{YYO} / \mathrm{cm}^{2}$ mortality of the nymphs with exposure time of $2.5,3$ and $3.5 \mathrm{~h}$, show $\mathrm{LT}_{50}$ of 4.8, 24 and $26.4 \mathrm{~h}$, respectively (Fig. 2c). an $\mathrm{LT}_{95}$ was only reached with the 


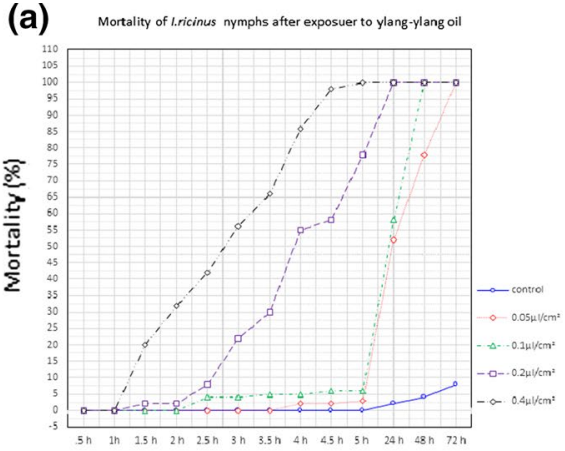

Exposuer time to YYO

(C) Mortality of liricinus nymphs after exposuer to Star Anis oil

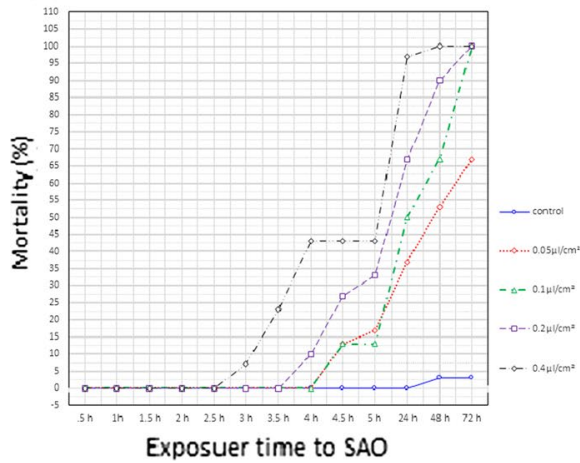

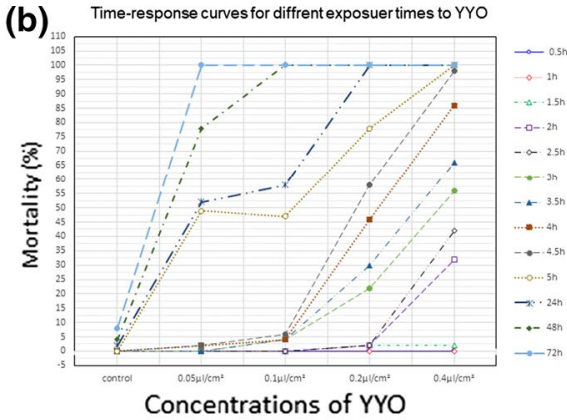

(d)

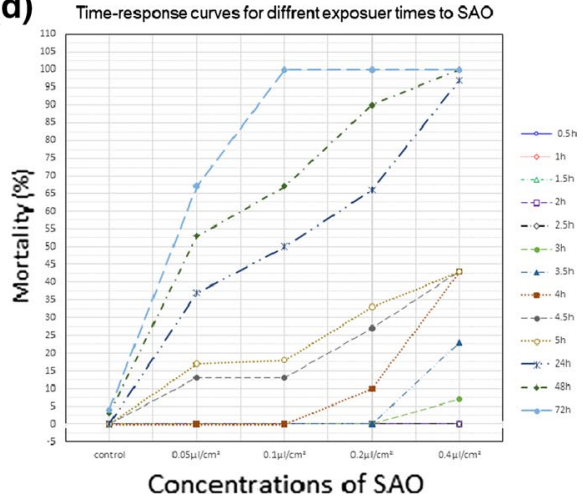

Fig. 1 a Mortality (\%) of Ixodes ricinus nymphs exposed to different concentrations of ylang-ylang oil (YYO) $\left(\mu \mathrm{l} / \mathrm{cm}^{2}\right)$ and different exposure times (hours) based on method A. From this graph the $\mathrm{LT}_{50}$ and $\mathrm{LT}_{95}$ were calculated (Table 1). b The $\mathrm{LC}_{50}$ and $\mathrm{LC}_{95}$ of YYO, based on method A, were calculated from the curves for different exposure times shown in this graph. (Table 1). c Mortality (\%) of I. ricinus nymphs exposed to different concentrations of star anise oil (SAO) $\left(\mu 1 / \mathrm{cm}^{2}\right)$ and different exposure times (hours) based on method A. From this graph the $\mathrm{LT}_{50}$ and $\mathrm{LT}_{95}$ were calculated (Table 2). d The $\mathrm{LC}_{50}$ and $\mathrm{LC}_{95}$ of $\mathrm{SAO}$, based on method A, were calculated from the curves for different exposure times shown in this graph. (Table 2)

Table 2 The lethal concentrations at different exposure times to star anise oil (SAO), and lethal times at different concentrations of SAO, in method A

\begin{tabular}{|c|c|c|c|c|c|}
\hline \multicolumn{3}{|c|}{ Lethal concentrations (LC) } & \multicolumn{3}{|c|}{ Lethal time (LT) } \\
\hline ET to SAO (h) & $\mathrm{LC}_{50}\left(\mu \mathrm{l} / \mathrm{cm}^{2}\right)$ & $\mathrm{LC}_{95}\left(\mu \mathrm{l} / \mathrm{cm}^{2}\right)$ & $\begin{array}{l}\text { Conc. of SAO } \\
\left(\mu \mathrm{l} / \mathrm{cm}^{2}\right)\end{array}$ & $\mathrm{LT}_{50}(\mathrm{~h})$ & $\mathrm{LT}_{95}(\mathrm{~h})$ \\
\hline $24 *$ & 0.1 & 0.39 & 0.05 & 42 & - \\
\hline 48 & 0.048 & 0.09 & 0.1 & 24 & 68 \\
\hline 72 & 0.034 & 0.048 & 0.2 & 18 & 60 \\
\hline & & & $0.4 *$ & 14 & 24 \\
\hline
\end{tabular}

*At $24 \mathrm{~h} \mathrm{LC} \mathrm{L}_{95}=0.39 \mu \mathrm{l} / \mathrm{cm}^{2}$ of $\mathrm{SAO} \approx 0.4 \mu \mathrm{l} / \mathrm{cm}^{2}$ of SAO, these results were calculated from the curves for different exposure times shown in Fig. 1c. * At $0.4 \mu \mathrm{l} / \mathrm{cm}^{2}$ of $\mathrm{SAO} \mathrm{LT}_{95}=24 \mathrm{~h}$, these results were calculated from the curves for different concentrations shown in Fig. 1d 
(a)

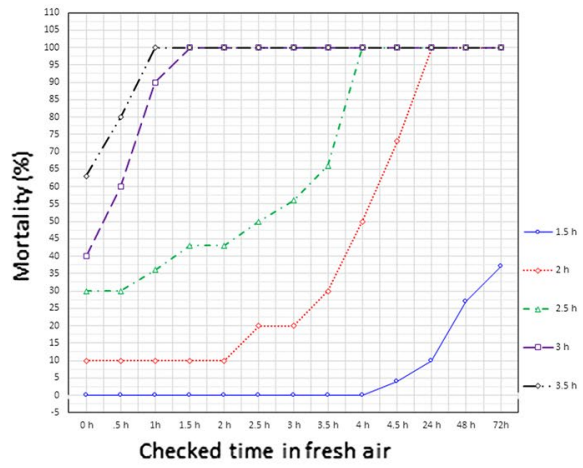

(c)

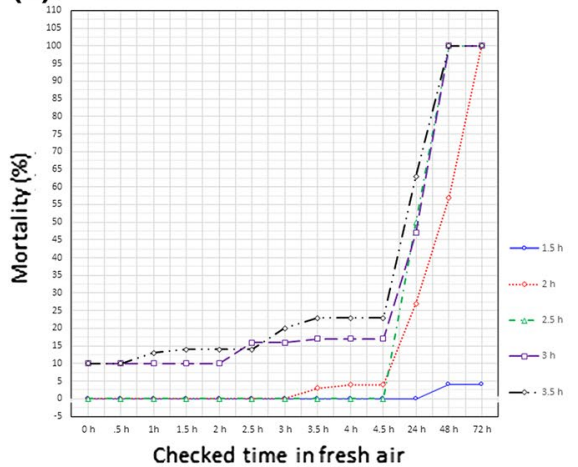

(b)

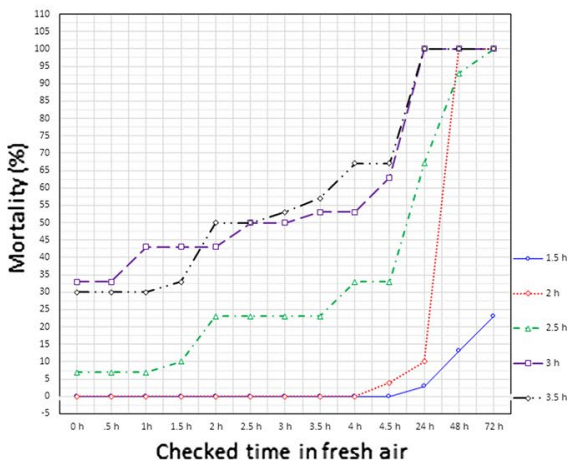

(d)

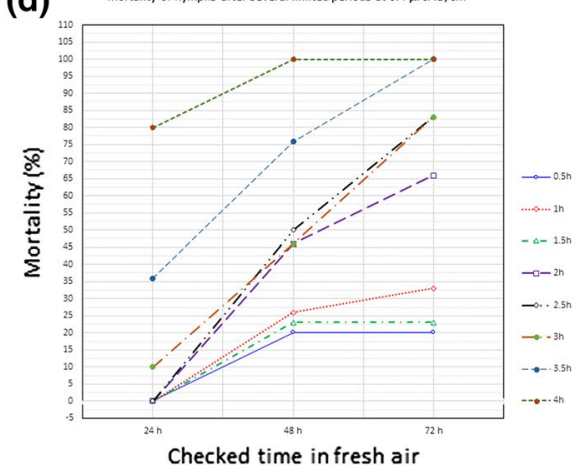

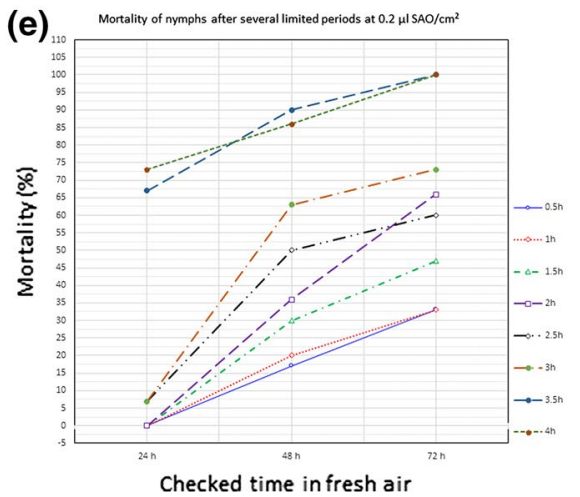

Fig. 2 a Mortality of Nymphs of Ixodes ricinus after several limited exposure times to $0.4 \mu 1$ ylang-ylang oil $(\mathrm{YYO}) / \mathrm{cm}^{2}$ shown after $3 \mathrm{~h}$ exposure to $\mathrm{YYO} \mathrm{LT}_{50}=3.2 \mathrm{~h}$ and $\mathrm{LT}_{95}=4.3 \mathrm{~h}$. And after $3.5 \mathrm{~h}$ exposure to YYO $\mathrm{LT}_{95}=4.4 \mathrm{~h}$. b Mortality of nymphs of . ricinus exposed to several limited periods of one fixed concentration $\left(0.2 \mu \mathrm{YYO} / \mathrm{cm}^{2}\right)$. After exposure to $\mathrm{YYO}$ for 3 and $3.5 \mathrm{~h}$ the $\mathrm{LT}_{50}=2.5,2 \mathrm{~h}$ and $\mathrm{LT}_{95}=4.9$ for both (based on method B). c Mortality of nymphs of I. ricinus exposed to several limited periods of one fixed concentration $(0.1 \mu \mathrm{l}$ $\mathrm{YYO} / \mathrm{cm}^{2}$ ). After exposure to YYO for $2.5,3$ and $3.5 \mathrm{~h}$ the $\mathrm{LT}_{50}=4.8,24$ and $26.4 \mathrm{~h}$, and the $\mathrm{LT}_{95}=43.2 \mathrm{~h}$ (based on method B). d Mortality of nymphs of I. ricinus exposed to several limited periods of one fixed concentration $\left(0.4 \mu \mathrm{l}\right.$ star anise oil $\left.(\mathrm{SAO}) / \mathrm{cm}^{2}\right)$. After exposure to SAO for $2,2.5,3$ and $3.5 \mathrm{~h}$ the $\mathrm{LT}_{50}=54,48,52$ and $32 \mathrm{~h}$, respectively. And after exposure to SAO for 3.5 and $4 \mathrm{~h}$ the $\mathrm{LT}_{95}=67$ and $42 \mathrm{~h}$ (based on method B). e Mortality of nymphs of $I$. ricinus exposed to several limited periods of one fixed concentration $\left(0.2 \mu \mathrm{l} \mathrm{SAO} / \mathrm{cm}^{2}\right)$. After exposure to SAO for 2, 2.5 and $3 \mathrm{~h}$ the $\mathrm{LT}_{50}=58,48$ and $42 \mathrm{~h}$, and after exposure to SAO for 3.5 and $4 \mathrm{~h}$ the $\mathrm{LT}_{95}=60$ and $62 \mathrm{~h}$ (based on method $\mathrm{B}$ ) 
nymphs exposed to $2.5 \mathrm{~h}$, while the nymphs that exposed to 3 and $3.5 \mathrm{~h}$ never reached $\mathrm{LT}_{95}$ even after $72 \mathrm{~h}$ (Fig. 2c).

\section{Star anise oil}

The analysis of variance showed that there was no significant difference in tick mortality between the SAO concentrations of 0.4 and $0.2 \mu \mathrm{l} / \mathrm{cm}^{2}$ that were tested $(\mathrm{F}=0.129$, $p=0.72$ ). However, at a concentration of $0.4 \mu \mathrm{SAO} / \mathrm{cm}^{2}$ (Fig. $2 \mathrm{~d}$ ) significant differences in mortality was found for different times of exposure $(\mathrm{F}=8.26, p<0.0001)$. After an ET of $0.5-1.5 \mathrm{~h}$, ticks that moved out from the impregnated area appeared weak and inactive but regained activity when exposed to fresh air, and after 1 week, and even after 1 week more than $50 \%$ were still alive. Conversely, the ticks that were exposed to SAO for 2.0, 2.5, 3.0 and $3.5 \mathrm{~h}$ reached $50 \%$ mortality $\left(\mathrm{LT}_{50}\right)$ with post-exposure times of 52, 50, 48, and $32 \mathrm{~h}$, respectively. In addition, the ticks that were exposed to SAO for 3.5 or $4.0 \mathrm{~h}$ reached $95 \%$ mortality $\left(\mathrm{LT}_{95}\right)$ after, respectively, 42 and $68 \mathrm{~h}$ in fresh air. Thus, for SAO at the concentrations tested, significant mortality $(p<0.001)$ was found only at $72 \mathrm{~h}$ post-exposure. On the other hand, results from the groups of ticks that were exposed to $0.2 \mu \mathrm{SAO} / \mathrm{cm}^{2}$ were not significant $(\mathrm{p}>0.05)$. The trends in mortality for these nymphs that were exposed to $0.2 \mu \mathrm{l} \mathrm{SAO} / \mathrm{cm}^{2}$ for more limited periods were ambiguous (Fig. 2e). After exposure for 2.0, 2.5 and $3.0 \mathrm{~h}$ the $\mathrm{LT}_{50}$ 's were 58, 48 and $42 \mathrm{~h}$, respectively, while exposures of 3.5 and $4.0 \mathrm{~h}$ gave an $\mathrm{LT}_{95}$ of 60 and $62 \mathrm{~h}$, respectively.

\section{Discussion}

Nymphs of $I$. ricinus are more abundant but less noticeable than adults and will therefore, pose more of a risk in disease transmission. In addition, nymphal ticks' non-specific host preference gives them considerable opportunities to acquire and transmit pathogens among numerous host species, including humans (Jensen and Jespersen 2005). This is why we focused on the nymphal stage in this study. Furthermore, I. ricinus seems to have increased in abundance in many locations in Northern Europe during the last decades (Gray 1984, 1991; Mejlon and Jaenson 1993; Jaenson et al. 2012a, b), which has also led to an increase in the number of human cases of tick-borne diseases (Lindgren and Jaenson 2006; Jaenson et al 2012a, b). Examples from Northern Europe include changes in tick distribution or abundance (Tälleklint and Jaenson 1998; Lindgren et al. 2000; Lindgren and Jaenson 2006) and incidences of Lyme borreliosis and TBE (Lindgren and Gustafson 2001; Bormane et al. 2004; Kampen et al. 2004; Jensen and Jespersen 2005; Bennett et al. 2006).

YYO and SAO are known to possess bacteriostatic and germicidal properties and are used to cure infections of the skin (Duke 2008; Kim et al 2007). The insecticidal property of YYO has also been tested on some human ectoparasites such as the human head louse Pediculus humanus capitis (Yang et al. 2004) on which YYO induced a high level of mortality (Heukelbach et al. 2006). In addition, YYO has a lethal effect on the mites Dermatophagoides farinae and D. pteronyssinus (Rim and Jee 2006), and linalool, which is a major constituent of YYO, has a significant and wide spectrum of acaricidal activity (Hink and Duffey 1990). SAO is toxic to adults of Blattella germanica, and it seems that one of SAO's components, (E)-anethole, is responsible for this effect (Chang and Ahn 2002). In addition, SAO has an ovicidal action against Tribolium castaneum and Sitophilus zeamais (Ho et al. 1995). 
The literature contains many studies that document the toxicity and acaricidal properties of the chemical components of YYO and SAO against many species of arthropods. Macchioni (2006) showed the acaricidal activity of Laurus nobilis oil, whose main components are 1,8-cineole (39.2\%) and linalool (7.4\%). Additionally, 1,8-cineole in molasses grass oil (Melinis minutiflora) produced $100 \%$ mortality in the cattle tick Boophilus microplus after 5 min' exposure (Prates et al. 1998). An $\alpha$-terpineol in tea tree oil (Melaleuca alternifolia) has acaricidal activity on Sarcoptes scabiei var. hominis (Walton et al. 2004). Iori et al. (2005) also showed that tea tree oil has acaricidal effect on I. ricinus, and Duke (1992) showed that SAO contains 85-200 ppm of $\alpha$-terpineol. These studies suggest that chemicals present in YYO and SAO may have a toxic effect on some tick species, which is supported by the results of this study.

Using a filter-paper method (method A), we found that YYO has strong significant acaricidal activity. This is especially obvious for $0.4 \mu \mathrm{YYO} / \mathrm{cm}^{2}$ for which mortality reaches $95 \%$ in a short time $(4.4 \mathrm{~h}$, Table 1$)$. Even with half this dose $\left(0.2 \mu \mathrm{YYO} / \mathrm{cm}^{2}\right), 95 \%$ mortality was reached within $24 \mathrm{~h}$, which is considered an acceptable outcome (Piesman 1993). At lower concentrations of YYO such as 0.05 and $0.1 \mu \mathrm{l} / \mathrm{cm}^{2}$ the acaricidal effect was present but weak. In fact, a significant repellency effect was observed only at a concentration of $0.2 \mu \mathrm{YYO} / \mathrm{cm}^{2}$ (Fawzeia Elmhalli personal observation).

With SAO the acaricidal activity was not as strong, but remained within the framework of what can be considered acceptable (Piesman 1993) in terms of lethal time $\left(\mathrm{LT}_{50}=14 \mathrm{~h}\right.$, $\mathrm{LT}_{95}=24 \mathrm{~h}$ at $0.4 \mu \mathrm{l} \mathrm{SAO} / \mathrm{cm}^{2}$ ). Piesman (1993) showed that the risk of B. burgdorferi transmission is low within the first $24 \mathrm{~h}$ of tick attachment but increases thereafter. On the other hand, with the TBE virus, transmission can occur almost immediately when the tick starts feeding (Bröker and Kollaritsch 2007). In general, ixodids take some time to locate an appropriate site to bite, so the first $24 \mathrm{~h}$ could be a critical time for acceptable protection against pathogen-infected ixodids. Therefore, concentrations as low as $0.4 \mu \mathrm{SAO} / \mathrm{cm}^{2}$ are acceptable for an acaricide against $I$. ricinus nymphs according to these results (Table 2). However, we also found that lower concentrations have little or no prophylactic effect.

In terms of exposure times, the results of method B show that nymphal mortality is correlated with the duration of exposure to YYO. This shows a distinct effect after $2 \mathrm{~h}$ with $0.4 \mu \mathrm{YYO} / \mathrm{cm}^{2}$, which results in $95 \%$ mortality within $24 \mathrm{~h}$ of exposure (Fig. 2a). This time to mortality is reduced to $4.4 \mathrm{~h}$ until $\mathrm{LC}_{95}$, with $3.5 \mathrm{~h}$ ' exposure. This is irrespective of whether the nymphs are moved to fresh air after their exposure or not. At $0.2 \mu \mathrm{YYO} / \mathrm{cm}^{2}$, 95\% mortality was reached within $24 \mathrm{~h}$ in fresh air (Fig. 2b), while with the lower concentration of $0.1 \mu \mathrm{YYO} / \mathrm{cm}^{2}$, only $50 \%$ mortality was reached after $24 \mathrm{~h}$ ' post-exposure times (Fig. 2c), which is considered non-significant (Piesman 1993).

With SAO significant lethality $\left(\mathrm{LC}_{50}\right)$ was only detected after exposure to $0.4 \mu \mathrm{SAO} /$ $\mathrm{cm}^{2}$ for a minimum of $3.5 \mathrm{~h}$ (Fig. 2d). This resulted in $50 \%$ mortality after $24 \mathrm{~h}$ in fresh air and $95 \%$ mortality after 24 and $48 \mathrm{~h}$ (Fig. $2 \mathrm{~d}$ ). With $0.2 \mu \mathrm{l} \mathrm{SAO} / \mathrm{cm}^{2}$, high mortality was reached only after 3.5 or more hours' exposure and at $24-48$ h' post-exposure (Fig. 2e). This is not an acceptable time frame (Piesman 1993), and suggested that SAO may not possess the same acaricidal potential as YYO.

The results shown here indicate that $\mathrm{YYO}$ is an effective acaricide against I. ricinus, particularly at a concentration of $0.4 \mu \mathrm{YYO} / \mathrm{cm}^{2}$. Although SAO also affects I. ricinus 'negatively', its impact is weaker than that of YYO, since SAO requires higher concentrations of oil and/or longer periods of exposure. Thus, both oils show potential utility as natural acaricides against $I$. ricinus. 
Acknowledgments I would thank T. G. T Jaenson (Uppsala University) for helpful advice during the experiments and S. L. Baldauf (Uppsala University) for help with writing the manuscript. I am grateful to The Ministry of Higher Education and Scientific Research of Libya especially, and also to The Swedish Research Council for Environment, Agricultural Sciences and Spatial Planning (Formas/SJFR); and The Swedish International Development Co-operation Agency (Sida/Sarec) for funding this work.

Open Access This article is distributed under the terms of the Creative Commons Attribution 4.0 International License (http://creativecommons.org/licenses/by/4.0/), which permits unrestricted use, distribution, and reproduction in any medium, provided you give appropriate credit to the original author(s) and the source, provide a link to the Creative Commons license, and indicate if changes were made.

\section{References}

Baratta MT, Dorman HJD, Deans SG, Figueiredo AC, Barroso QJG, Ruberto G (1998) Antimicrobial and antioxidant properties of some commercial essential oils. Flavo Fragr 13:235-244. https://doi. org/10.1002/(SICI)1099-1026(1998070)13:4\%3c235:AID-FFJ733\%3e3.0.CO;2-T

Benneet L, Halling A, Berglund J (2006) Increased incidence of Lyme borreliosis in southern Sweden following mild winters and during warm. humid summers. Eur Clin Microb Infect 25:426-432. https:// doi.org/10.1007/s10096-006-0167-2

Bormane A, Lucenko I, Duks A, Mavtchoutko V, Ranka R, Salmina K, Baumanis V (2004) Vectors of tickborne diseases and epidemiological situation in Latvia in 1993-2002. Med Microbiol 37:36-47. https:// doi.org/10.1016/S1433-1128(04)80007-X

Bröker M, Kollaritsch H (2007) After a tick bite in a tick-borne encephalitis virus endemic area: current positions about post-exposure treatment. Vaccine 26(7):863-868. https://doi.org/10.1016/j.vacci ne.2007.11.046

Chang KS, Ahn YJ (2002) Fumigant activity of (E)-anethole identified in Illicium verum fruit against Blattella germanica. School of Agricultural Biotechnology, Seoul National University, Republic of Korea, Suwon, pp 441-744. https://doi.org/10.1002/ps.435

De Souza Chagas AC, de Barros LD, Cotinguiba F, Furlan M, Giglioti R, de Sena Oliveira MC, Bizzo HR (2012) In vitro efficacy of plant extracts and synthesized substances on Rhipicephalus (Boophilus) Microplus (Acari: Ixodidae). Parasitol Res 110:295-303

Duke JA (1992) Handbook of phytochemical constituents of GRAS herbs and other economic plants. CRC Press, Boca Raton, FL. http://agris.fao.org/agris-search/search.do?recordID=US9320964

Duke JA (2008) Duke's Handbook of medicinal plants of latin America. CRC Press, Boca Raton, FL. ISBN 9781420043167

Estrada-Pena A, Jongejan F (1999) Ticks feeding on humans: a review of records on human-biting Ixodoidea with special reference to pathogen transmission. J Exp Appl Acarol 23:685-715. https://doi. org/10.1023/A:1006241108739

Gray JS (1984) Studies on the dynamics of active populations of the sheep tick, Ixodes ricinus L. in Co Wicklow, Ireland. J Acarol 25(2):167-178

Gray JS (1991) The development and seasonal activity of the tick, Ixodes ricinus: a vector of Lyme borreliosis. Rev Med Vet Entomol 79:323-333

Heukelbach J, Speare R, Canyon D (2006) Natural products and their application to the control of head lice: an evidence-based review. J Chem Natl Prod 81:308-440

Hink FW, Duffey ET (1990) Controlling ticks and fleas with linalool. J U.S Patent Genius Documents. $494,379,168$

Ho SH, Ma Y, Goh PM, Sim KY (1995) Star anise, Illicium uerum Hook f. as a potential grain protectant against Tribolium castaneum (Herbst) and Sitophilus reamais Motsch. J Postharvest Biol Technol 6:341-347. https://doi.org/10.1016/0925-5214(95)00015-X

Iori A, Grazioli D, Gentile E, Marano G, Salvatore G (2005) Acaricidal properties of the essential oil of Melaleuca alternifoila Cheel (tea tree oil) against nymphs of Ixodes ricinus. J Vet Parasitol 129:173176. https://doi.org/10.1016/j.vetpar.2004.11.035

Jaenson TG, Jaenson DG, Eisen L, Petersson E, Lindgren E (2012a) Changes in the geographical distribution and abundance of the tick Ixodes ricinus during the past 30 years in Sweden. Parasit Vectors 5:8. https://doi.org/10.1186/1756-3305-5-8 
Jaenson TG, Hjertqvist M, Bergström T, Lundkvist $\AA$ (2012b) Why is tick-borne encephalitis increasing? A review of the key factors causing the increasing incidence of human TBE in Sweden. Parasit Vectors 5:184. https://doi.org/10.1186/1756-3305-5-184

Jensen PM, Jespersen JB (2005) Five decades of tick-man interaction in Denmark an analysis. J Exp Appl Acarol 35:131-146. https://doi.org/10.1007/s10493-004-1991-7

Johnson RC, Schmid GP, Hyde FW, Steigerwalt AG, Brenner DJ (1984) Borrelia burgdorferi sp. nov.: etiologic Agent of Lyme Disease. Int J Syst Evol Microbiol 34:496-497. https://doi.org/10.1099/00207 713-34-4-496

Kampen H, Rötzel DC, Kurtenbach K, Maier WA, Seitz HM (2004) Substantial rise in the prevalence of Lyme borreliosis spirochetes in a region of western Germany over a 10-year period. J Appl Environ Microbiol 70:1576-1582. https://doi.org/10.1128/AEM.70.3.1576-1582.2004

Katinka P, Jaenson TG, Bæckström P, Borg-Karlson A-K (2008) Tick repellent substances in the essential oil of Tanacetum vulgare. J Med Entomol 45:88-93

Kim SI, Na YE, Yi JH, Kim BS, Ahn YJ (2007) Contact and fumigant toxicity of oriental medicinal plant extracts against Dermanyssus gallinae (Acari: Dermanyssidae). Vet Parasitol 145:377-382. https://doi. org/10.1016/j.vetpar.2006.12.021

Lindgren E, Gustafson R (2001) Tick-borne encephalitis in Sweden and climate change. Lancet 358:16-18. https://doi.org/10.1016/S0140-6736(00)05250-8

Lindgren E, Jaenson TGT (2006) Lyme borreliosis in Europe: influences of climate and climate change, epidemiology, ecology and adaptation measures. World Health Organization WHO, Geneva

Lindgren E, Tälleklint L, Polfeldt T (2000) Impact of climatic change on the northern distribution limit and population density of the disease-transmitting European tick Ixodes ricinus. J Environm Health Perspect 108:119-123

Macchioni F, Perrucci S, Cioni P, Morelli I (2006) Composition and Acaricidal Activity of Laurus novocanariensis and Laurus nobilis Essential Oils Against Psoroptes cuniculi. J Essential Oil Res https://doi. org/10.1080/10412905.2006.9699403

Manner H, Craig E (2006) Traditional tree initiative: species profiles for pacific island agroforestry. Permanent Agricultural Resources Publishers, Honolulu

Mejlon HA, Jaenson TGT (1993) Seasonal prevalence of Borrelia burgdorferi in Ixodes ricinus in different vegetation types in Sweden. J Med Entomol 42:352-358. https://doi.org/10.3109/00365549309008526

M'Fadyean SJ, Stockman S (1911) A new species of piroplasm found in the blood of british cattle. J Comp Pathol Ther 24:340-354. https://doi.org/10.1016/S0368-1742(11)80062-7

Papachristos DP, Karamanoli KI, Stamopoul DC, Menkissoglu-Spiroudi U (2004) The relationship between the chemical composition of three essential oils and their insecticidal activity against Acanthoscelides obtectus (Say). J Pest Manag Sci 60:514-520. https://doi.org/10.1002/ps.798

Piesman J (1993) Dynamics of Borrelia burgdorferi transmission by nymphal Ixodes dammini ticks. J Infect Dis 167:1082-1085. https://doi.org/10.1093/infdis/167.5.1082

Prates HT, Leite RC, Craveiro AA, Olivera AB (1998) Identification of some chemical components of the essential oil from molasses grass (Melinis minutiflora Beauv.) and their activity against cattle-tick (Boophilus microplus). J Braz Chem 2:0103-5053. https://doi.org/10.1590/S0103-505319980002000 13

Randolph SE (1998) Ticks are not insects: consequences of contrasting vector biology for transmission potential. J Parasitol Today 14:186-192. https://doi.org/10.1016/S0169-4758(98)01224-1

Rim I, Jee C (2006) Acaricidal effects of herb essential oils against Dermatophagoides farinae and D.pteronyssinus Acari: Pyroglyphidae and qualitative analysis of a herb Mentha pulegium pennyroyal. J Korean Parasitol 44(2):133-138. https://doi.org/10.3347/kjp.2006.44.2.133

Sarih MH, Jouda F, Gern L, Postic D (2003) First isolation of Borrelia burgdorferi sensu lato from Ixodes ricinus ticks in Morocco. J Vector-Borne Zon Dis 3:133-139. https://doi.org/10.1089/1530366037 68395834

Silva-Aguayo G (2004) Pesticides: chemistries/pesticide resistance. Botanical insecticides. In: Ware GW, Whitacre DM (eds) An introduction to insecticides, 4th ed, Radcliffe's IPM World Textbook, Willoughby, $\mathrm{OH}$

Sonenshine DE (2003) Ticks. In: Vincent HR, Ring TC (eds) Encyclopaedia of insects. Old Dominion University, Elsevier Science, Amsterdam, p 1132

Tälleklint L, Jaenson TGT (1998) Increasing geographical distribution and densityof Ixodes ricinus (Acari: Ixodidae) in central and northern Sweden. J Med Entom 35:521-526. https://doi.org/10.1093/jmede $\mathrm{nt} / 35.4 .521$

Walton SF, McKinnon M, Pizzutto S, Dougall A, Williams E, Currie BJ (2004) Acaricidal activity of Melaleuca alternifolia (Tea Tree) oil in vitro sensitivity of Sarcoptes scabiei var hominis to Terpinen-4-ol. J Arch Dermatol 140:563-566. https://doi.org/10.1001/archderm.140.5.563 
(WHO) World Health Organization (1996) Pesticides evaluation scheme division of control of tropical diseases. Report of the WHO Informal Consultation on the Evaluation and Testing of Insecticides. WHO. CTD/WHOPES/IC/96.1. pp 45

Yang YC, Lee HS, Clark JM, Ahn YJ (2004) Insecticidal activity of plant essential oils against Pediculus humanus capitis (Anoplura: Pediculidae). J Med Entomol 41(4):699-704. https://doi. org/10.1603/0022-2585-41.4.699

Zhioua E, Heyer K, Browning M, Ginsberg HS, LeBrun RA (1999) Pathogenicity of Bacillus thuringiensis variety kurstaki to Ixodes scapularis (Acari: Ixodidae). J Med Entomol 36:900-902. https://doi. org/10.1093/jmedent/36.6.900 